\title{
Income Inequality in Transitional Urban China: The Effect of Market versus State
}

\author{
Qiong Wu, Barry Goetz, David Hartmann, Yuan-Kang Wang \\ Department of Sociology, Western Michigan University, Kalamazoo, USA \\ Email: qiong.wu@wmich.edu
}

Received July $2^{\text {nd }}, 2012$; revised August $4^{\text {th }}, 2012$; accepted August $13^{\text {th }}, 2012$

\begin{abstract}
The rise of inequality in China is one of the most serious social problems in the reform era in China. Previous studies have debated the relative importance of human capital, political capital, and other factors in determining personal income. Using a new dataset from 2006 China General Social Survey (CGSS, 2006), the first author replicates earlier tests to measure whether the market or state has more impact on incomes as a way to the competing hypotheses related to human versus political capital. The results of the ordinary least squares regression analysis show no significance in party membership, state ownership, and work experience, while the first author does find high returns to education, which supports Nee's market transition theory. Moreover, the findings indicate that market sectors, including domestic private enterprises and foreign enterprises have remarkable advantages in earnings, and there is a great income gap between different regions, sectors, and within the sectors. To summarize, the market and state play a dual role in determining income in transitional urban China.
\end{abstract}

Keywords: Income Inequality; Urban China; Market Effect; State Effect

\section{Introduction}

China's Communist Revolution was founded upon the idea of equality of wealth. In pre-reform China, the society was relatively equal in income distribution and resource allocation. Since 1978, China has been carrying out a transformation from a socialist planned economy to market economy, along with a great social change from relative social egalitarianism to a new era of individualism and competition under the market mechanism.

Sir Arthur Lewis said, "development must be inegalitarian because it does not start in every part of the economy at the same time" (Lewis, 1976: p. 26). In terms of China, the government has started a policy to allow and encourage some people to get rich first and some regions to develop quickly, and coastal and urban areas obtained the priority to develop first and faster. As a result, the income gap between the rich and poor, between urban and rural areas, and between different regions has become larger.

Compared to the pre-reform era, though inequalities have increased dramatically between workers and professionals, eastern-coastal regions and western regions, "under a market system, everyone ostensibly has an opportunity to try for better jobs and income" (Tang \& Parish, 2000: p. 51). Chinese society has become more diverse. Specialization helps build a more organic society, in which an individual's needs are served by markets, rather than by the state.

However, according to the survey results from the national China Household Income Project 2002, 81.5\% of people think that the current situation on income distribution is not fair, and the 2006 China General Social Survey also indicated that over $50 \%$ of the respondents feel unfair about the income distribution. People's attitude towards the unfairness of income distribution, to some extent, reflects income inequality in China that ordinary people feel the widen gap between the rich and the poor, the urban-rural divide, between different social classes, and different regions. The income gap has become the most serious social problem in current China, far ahead of crime and corruption, which rank in second and third place based on a survey in 2004 (Xinhua, 2004).

In studies of social change and problems in the societal transformation in the state socialism, there are three contradictory theories regarding social transformation in post-socialist societies: 1) continuing bureaucratic politics (power continuity; 2) market transformation (structural transformation); 3) the mix solution of technocratic continuity (Tang \& Parish, 2000: p. 83).

Nee's market transition theory argues that "higher returns of education, which is among the best indicators of human productivity" (Nee, 1989: p. 666). The thesis of "power persistence" (Bian \& Logan, 1996) contends that political power of party cadres can be transformed into economic advantages on the course of the transition to a market economy. The politically-based privilege is still "deeply embedded in the economic situation" (p. 741). The argument of technocratic continuity suggests that the old technocratic managers with specialized skills would regain their advantages in the socialist economy and emerging as the new entrepreneurs in the market economy. The technocratic cadres "can maintain their positions through the acquired expertise" (Rona-Tas, 1994: p. 45).

Based on the literature, the whole theoretical debate comes down to considering competing hypotheses whether human capital or political capital is more important in determining personal income in urban China. Human capital include education, work experience, skills, parental education, etc. Political capital refer to party membership, working in the state sector, government and other power agencies, parental party membership, social contact that can get access to political capital. My 
research hypotheses are as follows:

Hypothesis 1: Human capital is the best indicator of income China today. In other words, higher educational credentials and more work experience will lead to higher earnings.

Hypothesis 2: Political capital (party membership) remains the best predictor of income in China today.

"Communist Party membership continues to yield an income advantage to workers and workers whose jobs hold redistributive power earn more" according to Bian and Logan's (1996) analysis on survey conducted in Tianjin, China in 1988 and 1993. Bian, Shu, and Logan (2001) also found that during the post-1978 reform era, "party membership had a significant effect on mobility into elite positions of political and managerial authority, and college education increased party members' chances of moving into positions of political authority but not into managerial positions within the state sector" (p. 832).

Hypothesis 3: The role of work unit sector and state ownership remains significant in determining income.

With an analysis of data survey collected in Shanghai, Xi' an and Wuhan in 1999, Xie and $\mathrm{Wu}$ (2008) indicates that "the danwei (work unit) continues to play a very important role in determining the economic well-being" (p. 13), and it still serves as "a major agent of social stratification in urban China" (p. 6).

In this paper, the first author addresses the issue of the theoretical debate in the literature on the research on social inequality in China by using a newer and different national dataset from CGSS, 2006 as a way to the competing hypotheses related to human versus political capital. The fundamental questions in this study are focused on: 1) Do income returns more on political capital (party membership) or human capital (education and work experience)? 2) How do these changes related to trends in aggregate inequality?

\section{Data and Variables}

In this paper, the first author employs individual-level data from the urban samples of the 2006 China General Social Survey (CGSS, 2006) under the joint sponsorship of Survey Research Center, Hong Kong University of Science and Technology, and Department of Sociology, Renmin University of China.

The CGSS is an annual or biannual questionnaire survey of China's urban and rural households. It aims to "monitor systematically the changing relationship between social structure and quality of life in urban and rural China"

(http://www.ust.hk/ websosc/survey/GSS_e.html). The survey program started from 2003, and the first dataset only covered the urban areas. In 2005, rural areas were added. The data of 2006 encompasses three sections: urban, rural and family questionnaires. For this paper, the first author only used the urban data of 2006, for analysis.

The surveys were conducted during September 2006 to October 2006 with 1610 variables and 10,151 cases (6013 cases in urban areas). A multistage cluster sampling procedure selected 28 provinces and municipalities. The respondents are from the age of 18 to 69 , in randomly selected 10,000 households in 28 provinces and cities nation-wide. The urban questionnaires contained personal general information, work experience, current work situation, family situation, and attitudes towards the

\footnotetext{
1"The term danwei or work unit refers to all work organizations in general, but was often used to refer to state economic enterprises in particular" (Wu, 2002: p. 1073).
}

society.

In order to estimate the relationships between income distribution and several socio-demographic characteristics of individuals, my analyses rely on OLS regression to predict total individual income in urban China. Table 1 lists all the variables used in the study.

"Hukou" is a particular household registration system in China. Dating back about 2000 years ago, when Qin Dynasty united the whole China, and set up this household registration system to collect taxes according to the number of people. After the Communist Party established the People's Republic of China, the Communist regime revived it in 1955 to keep poor rural farmers from flooding into the cities in case that the "extensive rural-to-urban migration would undercut the attempt to develop an urban welfare state". The "Hukou" registration system "classified each member of the population as having agricultural (rural) or nonagricultural (urban) status (Hukou), with a sharp differentiation of rights and privileges and extremely stringent conditions for converting from rural to urban status" (Wu \& Treiman, 2004: p. 363).

Due to the restriction of "Hukou", those who move to large cities to work or study but do not have the local "Hukou" cannot enjoy all kinds of benefits as the citizens, and have to go back to their hometown to get a marriage license, apply for a passport or take the national university entrance exam. Rather, the "Hukou" system creates unfair advantages for those who live in large cities especially Beijing and Shanghai. Because in China, most highly regarded universities and hospitals locate in large cities, and those institutions provide more preferential policies to the local Hukou-holders. Moreover, most local enterprises tend to favor in those who are local residents. Thus, those who have the urban "Hukou" of large cities tend to have advantages over those who are originally from smaller places.

In pre-reform China, Chinese urban society was organized by each work unit dominated by the state. "In Chinese official statistics, the danwei ${ }^{1}$ or work unit is defined as an independent accounting unit with three characteristics: 1) administratively, it is an independent organization; 2) fiscally, it has an independent budget and produces its own accounting tables of earnings and deficits; 3) financially, it has independent accounts in banks and has legal rights to sign contracts with government or business entities" (Bian, 1994: p. 23). The role of danwei or work unit was extremely significant that it defined one's social, economic, and political life. Individuals depended on danwei for almost everything. Without a work unit, it was difficult to survive in a city because housing, food, and other social services were hardly available through the market.

After the reform, with the emerging of private sector includeing private enterprises, foreign companies, joint-ventures, and the self-employed, the role of danwei has lost some of its importance compared to the era of pre-reform, because through danwei is no longer the only way to get all social services, the market has made it more diverse. However, danwei does not disappear with the challenge of the market, and remains the main agent of social stratification in contemporary urban China.

Except danwei or work unit, "ownership type has always been an important factor in determining income", (Wang, 2008: p. 113). According to the questionnaire in CGSS, 2006, types of work unit and ownership are two separate but close-related questions. The types of work unit include government and party agencies, enterprises, institutions, social organizations, and individual operation or self-employed. Among these work or- 
Table 1.

Description of predictors for the analysis of individual income inequality in urban China.

\begin{tabular}{|c|c|}
\hline Variables & Description \\
\hline Total income (income 2005) & Personal yearly total income in 2005 (Yuan) \\
\hline Gender (gender) & $1=$ female $; 2=$ male \\
\hline Work experience (workexp) & Work experience is measured by subtracting the end year of a job from the start year (in years) \\
\hline Education level (education) & $\begin{array}{l}\text { Education is measured by eight levels } \\
1=\text { never schooled } \\
2=\text { classes for eliminating illiteracy } \\
3=\text { elementary School } \\
4=\text { middle School } \\
5=\text { high School } \\
6=\text { junior college } \\
7=\text { college/university } \\
8=\text { graduate }\end{array}$ \\
\hline Foreign language skill (lanskill) & $\begin{array}{l}\text { Four categories: } \\
1=\text { not at all } \\
2=\text { know a little } \\
3=\text { somewhat fluent } \\
4=\text { very fluent }\end{array}$ \\
\hline Type of "Hukou” (“Hukou”) & $\begin{array}{l}\text { Four categories: } \\
1=\text { urban "Hukou" in small cities/towns } \\
2=\text { urban "Hukou" in middle cities } \\
3=\text { urban "Hukou" in large cities (Municipalities and Provincial capital) } \\
4=\text { rural "Hukou" }\end{array}$ \\
\hline Party membership (party) & $\begin{array}{l}\text { Two categories: } \\
1=\text { member of communist party of China or communist youth league of China; } \\
2=\text { non-communist party member (other parties or no party) }\end{array}$ \\
\hline $\begin{array}{l}\text { Type of workplace (including danwei and other } \\
\text { workplaces in the market sector) (workplace) }\end{array}$ & $\begin{array}{l}1=\text { government agencies and state-owned enterprises (SOEs) } \\
2=\text { collective enterprises } \\
3=\text { private enterprises } \\
4=\text { foreign-invested enterprises (including Hong Kong, Macao, and Taiwan) } \\
5=\text { institutions } \\
6=\text { social organizations or public organizations } \\
7=\text { other }\end{array}$ \\
\hline Geographic or residential location (location) & $\begin{array}{l}1=\text { eastern coastal regions } \\
2=\text { central regions } \\
3=\text { western regions }\end{array}$ \\
\hline
\end{tabular}

Source: data from CGSS, 2006.

ganizations, only those who answered enterprises and institutions have to answer the second question about the type of sector or ownership. The options are state-owned, collective, private enterprises, enterprises from Hong Kong, Macao and Taiwan, and foreign-invested or owned enterprises. Since all institutions are government-sponsored, the first author combine the type of work unit and ownership into one variable Workplace to distinguish the different types of enterprises. I distinguish the following type of workplace in urban China:

1) Government agencies and SOEs, which include all levels of government and Communist party agencies and stateowned enterprises is the reference group.

2) Collective enterprises are not directly supported by the state but are mostly sponsored by local governments.

3) Private enterprises include private firms and individual operation or self-employed.

4) Foreign enterprises include foreign-owned, foreign-invested companies and the enterprises from Hong Kong, Macao, and Taiwan.

5) Institutions or public institutions include schools, research institutions, libraries, museums, hospitals and publishing houses, are the backbone of public service providers in China.

6) Social organizations or public organizations are sets of as- sociations emerged in the late 1980 s with official encouragement, consisting of genuine NGOs and government-organized NGOs.

\section{7) Others.}

Residential location is a control variable that the first author will use in the analysis. In the survey data, it covers all the provinces and municipalities in China except Qinghai, Tibet and Ningxia, which are all located in the west. The first author recoded the cities by geographical location into three categories: eastern coastal $(=1)$, central $(=2)$, and western regions $(=3)$.

In the study, the dependent variable is the natural logged personal total income in 2005. The independent variables include gender, education level, foreign language skill, years of work experience, party membership, type of workplace, type of "Hukou" and residential location. The analyses rely on OLS regression to predict the total individual income in urban China. In the analysis, I attempt to find out "trends in the importance of individual-level earnings determinants and their conesquences for trends in overall inequality" (Hauser \& Xie, 2003: p. 52).

\section{Methods}

In order to estimate the relationships between the logged an- 
nual income and several predictors including gender, work experience, education, foreign language skill, party membership, type of "Hukou", geographical location, and workplace, my analyses rely on Ordinary Least Squares (OLS) regression to predict total individual income in urban China.

Before developing a multiple regression, the first author did several preliminary analyses, including univariate descriptive analysis, bivariate scatterplots of the income with age and years of education. Table 2 summarizes the descriptive statistics of all the variables in the analysis (see Table 2).

The mean of personal total yearly income in 2005 is 18383.343 RMB (yuan), the standard deviation is 23214.25. The mean of education level is 4.8378 , which roughly reaches high school level, and the standard deviation is 1.185 . The mean of level of foreign language skill is 1.5873 (approximately the level of knowing a little of foreign language), and the standard deviation is .58826 . Among all the respondents, there are $17.7 \%$ are members of the Communist Party of China or the

Table 2.

Descriptive statistics.

\begin{tabular}{lcccc}
\hline & $\mathrm{N}$ & Mean & $\begin{array}{c}\text { Standard } \\
\text { Deviation }\end{array}$ & $\begin{array}{c}\text { Standard } \\
\text { Error }\end{array}$ \\
\hline Total Income 2005 & 3109 & 18383.343 & 23214.25 & 416.336 \\
Education Level & 3109 & 4.8378 & 1.185 & .0213 \\
Foreign Language Skill & 3109 & 1.5873 & .58826 & .01055 \\
& $\mathrm{~N}$ & Percent & &
\end{tabular}

Party Membership

\begin{tabular}{|c|c|c|}
\hline $\begin{array}{l}1=\text { Communist Party \& } \\
\text { Communist } \\
\text { Youth League }\end{array}$ & 550 & 17.7 \\
\hline \multicolumn{3}{|l|}{ Gender } \\
\hline $1=$ male & 1697 & 54.6 \\
\hline $2=$ female & 1412 & 45.4 \\
\hline \multicolumn{3}{|l|}{ "Hukou" } \\
\hline $1=$ Small cities & 844 & 27.1 \\
\hline $2=$ Middle cities & 635 & 20.4 \\
\hline $3=$ Large cities & 950 & 30.6 \\
\hline $4=$ Rural & 680 & 21.9 \\
\hline \multicolumn{3}{|l|}{ Workplace } \\
\hline $\begin{array}{l}1=\text { Government Agencies } \\
\text { and SOEs }\end{array}$ & 1020 & 32.8 \\
\hline $2=$ Collective Enterprises & 334 & 10.7 \\
\hline $3=$ Private Enterprises & 993 & 31.92 \\
\hline $4=$ Foreign Enterprises & 48 & 1.52 \\
\hline $5=$ Institutions & 519 & 16.68 \\
\hline $6=$ Social Organizations & 74 & 2.38 \\
\hline $7=$ Others & 122 & 3.94 \\
\hline \multicolumn{3}{|l|}{ Residential Location } \\
\hline $1=$ Eastern Coastal Regions & 1731 & 55.7 \\
\hline $2=$ Central Regions & 880 & 28.3 \\
\hline $3=$ Western Regions & 498 & 16 \\
\hline
\end{tabular}

Note: used the results from averaging the five imputations. Source: data from CGSS, 2006.
Communist Youth League, $82.3 \%$ are from other political parties, and those who do not belong to any parties. There are $54.6 \%$ of males, and $45.4 \%$ of females. For the type of "Hukou", $27.1 \%$ are from small cities, $20.4 \%$ are from middle-size cities, $30.6 \%$ are from large cities, and $21.9 \%$ hold the rural "Hukou". In terms of the type of work place, $32.8 \%$ of the respondents work at government agencies or state-owned enterprises, $10.7 \%$ work at collective enterprises, $31.92 \%$ are employed at private enterprises, $1.52 \%$ work for foreign enterprises, $16.68 \%$ work at institutions, $2.38 \%$ work at social organizations, and 3.94\% work for other workplace.

Then the first author ran the regression model and tested the residuals for normality, and found that the residuals of the dependent variable income are not normal distributed based on a significant Kolmogorov-Smirnov test. Accordingly, I logged income, and used Inincome as the dependent variable in subsequent analyses. Though according to the residual of the regression model using the natural logged income variable were still not perfectly normal distributed, the distribution looked much closer to normal. With only a slight departure from normality and a very large sample size, the first author is confident that the results of the regression analysis are robust.

Then the first author generated new scatterplots with the logged income, and found a nonlinear relationship between logged income and years of work experience. Thus, the first author used curve estimation to check for the nonlinearity. By doing the curve fit analysis and incremental F-test between linear and quadratic models; the first author found that the quadratic model is the best in this case. After detecting and correcting for nonlinearity, I ran a regression and performed the White's test for homoskedasticity and found that the first author needed to correct for heteroskedasticity using weighted least squares regression which yielded homoskedastic residuals.

According to the results of collinearity diagnostics, all the indexes, including VIF, square root of VIF, Tolerance, Eigenvalue, and condition index, show that there is no problem of multicollinearity when excluded the variable workexp.

\section{Results}

Having fulfilled all the assumptions of OLS regression and corrected for the violation, my regression now is the best linear unbiased estimator.

Table 3 presents the main results from the final regression model with location as the control variable. From the table, we can see that the adjusted $\mathrm{R}^{2}$ is .2652 , which indicates that $26.52 \%$ of the variation in logged income in 2005 is explained by the sets of independent variables. Also, $\mathrm{R}$ is .5192 , which shows that there is a statistically significant and moderate relationship between logged income in 2005 and the sets of independent variables (See Table 3).

Table 3 also shows the coefficients of each independent variable. The unstandardized slope B for Education is .2136. Taking the antilog and multiplying by 100 , shows that for each additional level of education, there is a 23.8 percent increase in earning. The unstandardized slope B for Lanskill is .0742. Taking the antilog and multiplying by 100 , shows that for each additional level of foreign language skill, there is a 7.7 percent increase in earnings. The unstandardized slope B for Female is -.2582 . Taking the antilog and multiplying by 100 , shows that females earn 22.8 percent less than males. The unstandardized slope B for Small is -.2654 . Taking the antilog and multiply- 
Table 3.

Regression results for LN (Income05) with location as control variable.

\begin{tabular}{|c|c|c|c|c|c|c|}
\hline Variable & B & SE B & Beta & $\mathrm{T}$ & $\mathrm{Sig}$ & $(\operatorname{Exp}(B)-1) * 100$ \\
\hline Education & .2136 & .0156 & .309 & 13.813 & $0^{* *}$ & 23.8 \\
\hline Lanskill & .0742 & .0272 & .0544 & 2.7176 & $.0158^{*}$ & 7.7 \\
\hline Small & -.2654 & .0348 & -.143 & -7.6298 & $0^{* *}$ & -23.3 \\
\hline Mid & -.1458 & .0358 & .0754 & 4.0694 & $.0002^{* *}$ & -13.6 \\
\hline Rural & -.1668 & .0476 & .0686 & 3.4948 & $.0016^{* *}$ & -15.4 \\
\hline female & -.2582 & .0268 & -.1562 & -9.6698 & $0^{* *}$ & -22.8 \\
\hline Private & .0898 & .0382 & .0464 & 2.3554 & $.0456^{*}$ & 9.4 \\
\hline Foreign & .554 & .1126 & .0808 & 4.966 & $0^{* *}$ & 74.0 \\
\hline Central & -.3014 & .0314 & -.1676 & -9.5776 & $0^{* *}$ & -26.022 \\
\hline Western & -.3802 & .0376 & -.1726 & -10.119 & $0^{* *}$ & -31.6 \\
\hline (constant) & 8.8012 & .0916 & & 95.873 & $0 * *$ & \\
\hline Collective & -.0806 & .0458 & -.0308 & -1.7658 & .0974 & \\
\hline Institution & .0252 & .0356 & .013 & .7056 & .497 & \\
\hline Socialorg & -.2042 & .1074 & -.0302 & -1.8678 & .128 & \\
\hline Nonccp & -.072 & .0348 & -.0352 & -2.0518 & .0738 & \\
\hline Other & -.01 & .093 & .0076 & -.4274 & .2584 & \\
\hline Workdev & .0008 & .002 & .0092 & .427 & .6752 & \\
\hline Workdev ${ }^{2}$ & 0 & 0 & -.0256 & -1.26 & 1.121 & \\
\hline $\mathrm{R}$ & .5192 & & & & & \\
\hline Adjusted $\mathrm{R}^{2}$ & .2652 & & & & & \\
\hline Std. Error of the Estimate & 1.00427 & & & & & \\
\hline
\end{tabular}

Note: used the results from averaging the five imputations. ${ }^{*} p<.05,{ }^{* *} p<.01$. Source: data from CGSS, 2006.

ing by 100 , shows that that those who have the urban "Hukou" of small cities tend to have 23.3 percent lower income than those who hold the urban "Hukou" of large cities. The unstandardized slope B for Mid is -.1458 . Taking the antilog and multiplying by 100 , shows that that those who have the urban "Hukou" of middle cities tend to have 13.6 percent lower income than those who hold the urban "Hukou" of large cities. The unstandardized slope B for Rural is -.1668 . Taking the antilog and multiplying by 100 , shows that that those who have the rural "Hukou" tend to have 15.4 percent lower income than those who hold the urban "Hukou" of large cities. The unstandardized slope B for Private is .0898. Taking the antilog and multiplying by 100 , shows that those who work at private enterprises or engage in the private business earn 9.4 percent more than those who work for government and SOEs. The unstandardized slope B for Foreign is .1126. Taking the antilog and multiplying by 100 , shows that those who work at foreign enterprises, including the enterprises from Hong Kong, Macao, and Taiwan, earn 74 percent more than those who work for government and SOEs. The unstandardized slope B for Central is -.3014 . Taking the antilog and multiplying by 100 , shows that those who live in the central regions earn 26.02 percent less than those who live in the eastern coastal areas. The unstandardized slope B for Western is -.3802. Taking the antilog and multiplying by 100 , shows that those who live in the western regions earn 31.6 percent less than those who live in the eastern coastal areas. The rests of predictors, Collective, Institution, socialorg, nonccp, Other, Workdev, Workdev2, are not statisti- cally significant $(p>.05)$.

Table 4 displays the OLS regression coefficients for the model without geographic variables. In Table 5, I report the OLS regression estimates for two models of income determination. Model 1 is a model with all the predictors. In Model1, only the variables education level, foreign language skill, Hukou dummies, Gender dummy, Workplace dummies (Private and Foreign) have significant effects on earnings. In Model 2, I exclude place of residence as a set of dummy variables and find that the estimates of all the predictors increase slightly, but variables party membership dummy, work experience, and workplace dummies (Collective, Institution, socialorg, Other) are not statistically significant (See Table 4).

Based on my results, in both models (See Table 5), education is the best indicator to predict personal income, and in my findings, education has a rate of $24.8 \%$, which is much higher than previous estimates (Xie \& Hannum, 1996; Wu \& Xie, 2002; Zhou, 2000). In addition, as part of education, foreign language skill enjoys a 7.7-percent advantage, which also confirm the significance of human capital in determining earnings.

Work experience, another conventional measurement of human capital, has no linear relationship with the dependent variable in the regression model. After conducted curve estimation, I set up a quadratic model for work experience by computing workdev and workdev 2. However, the result shows that workdev and workdev 2 are not significant. Thus, overall, work experience is not significant in either model. This result is different from Xie and Hannum's findings that work experience has a 
Table 4.

Regression results for $L N$ (Income 05) without location as control variable.

\begin{tabular}{|c|c|c|c|c|c|c|}
\hline Variable & B & SE B & Beta & $\mathrm{T}$ & Sig & $(\operatorname{Exp}(B)-1) * 100$ \\
\hline Education & .2216 & .016 & .3196 & 13.992 & $0^{* *}$ & 24.8 \\
\hline Lanskill & .1076 & .0276 & .0786 & 3.8708 & $.0004^{* *}$ & 11.4 \\
\hline Small & -.34 & .0348 & -.183 & -9.761 & $0^{* *}$ & -28.8 \\
\hline Mid & -.2414 & .0358 & -.124 & -6.7642 & $0^{* *}$ & -21.4 \\
\hline Rural & -.2032 & .0488 & -.083 & -4.1594 & $0^{* *}$ & -18.4 \\
\hline female & -.254 & .0272 & -.1538 & -9.307 & $0^{* *}$ & -22.4 \\
\hline Private & .1238 & .0392 & .0634 & 3.1598 & $.0064^{* *}$ & 13.2 \\
\hline Foreign & .618 & .114 & .0918 & 5.5116 & $0^{* *}$ & 85.5 \\
\hline (Constant) & 8.5718 & .0918 & & 93.3516 & $0^{* *}$ & \\
\hline Collective & -.035801 & .0456 & -.014 & -.791 & .4778 & \\
\hline Institution & .0292 & .0364 & .0156 & .805 & .437 & \\
\hline Socialorg & -.1396 & .1092 & -.0206 & -1.2568 & .3308 & \\
\hline Noncep & -.061 & .036 & -.0296 & -1.69 & .1432 & \\
\hline Other & .0158 & .0948 & -.0064 & -.334 & .0828 & \\
\hline Workdev & $-1.47 \mathrm{E}-05$ & .002 & .0012 & .0464 & .861 & \\
\hline Workdev ${ }^{2}$ & $-5.16 \mathrm{E}-05$ & 0 & -.0076 & -.3762 & .6888 & \\
\hline $\mathrm{R}$ & .4828 & & & & & \\
\hline Adjusted $\mathrm{R}^{2}$ & .233 & & & & & \\
\hline Std. Error of the Estimate & 1.00349 & & & & & \\
\hline
\end{tabular}

Note: used the results from averaging the five imputations. ${ }^{*} p<.05,{ }^{* *} p<.01$; Source: data from CGSS, 2006.

Table 5.

OLS coefficients from multiple linear regression of logged income in 2005 on selected independent variables and control variables.

\begin{tabular}{|c|c|c|}
\hline Variable & Model 1 (geographic variables controlled) & Model 2 \\
\hline Education level & $.2136^{* *}$ & $.2216^{* *}$ \\
\hline Foreign language skill & $.0742^{*}$ & $.1076^{* *}$ \\
\hline Hukou dummy (small = 1) & $-.2654^{* *}$ & $-.34^{* *}$ \\
\hline Hukou dummy $(\mathrm{mid}=1)$ & $-.1458^{* *}$ & $-.2414^{* *}$ \\
\hline Hukou dummy (rural = 1) & $-.1668^{* *}$ & $-.2032^{* *}$ \\
\hline Gender $($ female $=1)$ & $-.2582^{* *}$ & $-.254^{* *}$ \\
\hline Workplace dummy (private $=1$ ) & $.0898^{*}$ & $.1238^{* *}$ \\
\hline Workplace dummy (foreign $=1$ ) & $.554^{* *}$ & $.618^{* *}$ \\
\hline Residential location dummy (central) & $-.3014^{* *}$ & - \\
\hline Residential location dummy (western) & $-.3802^{* *}$ & - \\
\hline Workplace dummy $($ collective $=1)$ & -.0806 & -.0358 \\
\hline Workplace dummy (institution $=1$ ) & .0252 & .0292 \\
\hline Workplace dummy (socialorg $=1$ ) & -.2042 & -.1396 \\
\hline Party dummy (nonccp = 1) & -.072 & -.061 \\
\hline Workplace dummy $($ other $=1)$ & -.01 & .0158 \\
\hline Work experience (workdev) & .0008 & $-1.47 \mathrm{E}-05$ \\
\hline Work experience (workdev 2) & 0 & $-5.16 \mathrm{E}-05$ \\
\hline (Constant) & 8.8012 & 8.5718 \\
\hline $\mathrm{R}$ & .5192 & .4828 \\
\hline Adjusted $\mathrm{R}^{2}$ & .2652 & .233 \\
\hline
\end{tabular}

Note: ${ }^{*} p<.05,{ }^{* *} p<.01$. Source: data from CGSS, 2006 . 
positive but concave effect on logged income. Thus, I partially approve my hypothesis that education has the greatest impact in determining income distribution, while work experience does not show much significance.

Beyond my expectation, party membership is not significant in either model. This suggests that party membership has little impact on earnings, and weak support for hypothesis 2. Compared to government agencies and state-owned enterprises, where accumulate the redistributive power and political capital, collective enterprises, public institutions and social organizations, which have more or less connections or relationships with the state reveal no remarkable advantages in earnings. However, private sector (private and foreign enterprises) demonstrates considerable disparity on income. Beyond the regional income differences in urban China, "the gap incomes between the different state and non-state sectors has become more important in explaining social inequality as whole, with the rapid growth of the foreign-invested and domestic private economies" (Guan, 2001: p. 246).

My findings also suggest that gender difference in earnings is also estimated to be large, with females earning 22.8 percent less than males. "Hukou" is still playing a crucial role in that large cities' residents earn 23.3 percent more than "Hukou"holders in small cities, 13.6 percent more than citizens in middle cities, and 15.4 percent more than those who originally from rural areas. Regional income disparities are also evident. Residents in eastern coastal areas tend to earn $26.02 \%$ more than those who live the central China $31.6 \%$ more than the people in the west.

I do find high returns to education, but fail to find high returns to work experience and party membership. And I did not find the significant effect on work unit sector and state ownership either. These findings are consistent with Nee's prediction that the significance of political power declines with the process of the marketization, and "the income determination will depend more on market credentials (such as education), and less on political factors as economic reform advances" (Xie, 2008: p. 195).

\section{Discussion}

In this paper, I have examined the determinants of income in urban China based on the data of 2006. My hypotheses regarding the role of educational credentials was generally supported in both analyses and held up when various controls were introduced. According to the results from the regression models, working at market sector firms, especially foreign enterprises are the most predominant in determining the income distribution in urban China.

\section{Does Political Capital or Power Really Decline Significantly?}

Returns to political capital or power "is operationalized in three ways: a) party membership, b) cadre position, and c) jobs with redistributive power" (Bian, 2002: p. 100). In China, not everyone can become a member of Communist Party. There are mainly two ways to apply for a membership of Chinese Communist Party. One way is that first one should join the Communist Youth League in middle school or high school, and until when he becomes an adult ( $\geq 18$ years old) and enters a college or university, he can write an application letter to show his desire and loyalty to the party. A party membership can be an advantage to find a job in government or party agencies after graduation. Another way to be a party member is to apply at work units, such as public institutions, SOEs. For both ways, "to achieve Chinese Communist Party membership, individuals must pass through five 'loyalty filters' (Walder, 1995): 1) self-selection; 2) political participation; 3) daily monitoring; 4) closed-door evaluation; and 5) probationary examination" (Bian, Shu, \& Logan, 2001: p. 813). Nowadays, the Chinese Communist Party tends to recruit educated youths and professional, which indicates that the role of educational credentials has become more and more important.

While variables related political capital did not turn out to be significant, things does not mean that party membership ceases to be an important factor in determining income. For example, "grey income is not included in the survey data and the limitation of my current research that does not partition cadre position into the party officials, government bureaucrats, and managers in SOEs".

Income distribution in the foreign enterprises and private companies are directly reflected in salaries, while in the government agencies and SOEs, the base wages may be lower than the workers in foreign and private enterprises, but the hidden bonuses and other forms of welfare benefit including allowance for transportation as well food, a housing packages, medical insurance, unemployment insurance and annuity. Moreover, many SOEs assumed monopoly positions in the new market economy after the structural reforms. Those monopolized enterprises, such as China Mobile, State Grid, China Telecom and China National Petroleum Corporation occupy the most important and profitable industries, such as mining industry, banking, communication and telecom. With the powerful supporting polices and ample and stable financial support from the state, the profits of these SOEs rose tremendously given the size and importance of these enterprises in the state sector it would be hard to conclude that political capital has no influence on income.

Moreover, the "grey income" of the state bureaucrats has great widen the income gap that $54 \%$ of the respondents of CGSS, 2006 recognize the huge gap between the cadre and the mass (poor vs rich has $57.7 \%$ ). In light of this, most people do realize the existence of the "grey income". According to Xiaolu Wang's research, "the government's statistics omit roughly RMB 9.26 trillion (about US\$1.36 trillion) in 'invisible' income-that is, money earned illegally and under the table or not declared to tax authorities"

(http://www.knowledgeatwharton.com.cn/index.cfm?fa=viewA rticle\&Articleid=2284\&languageid=1).

What's more, "as private economic activities became legal and market competition played a greater role in economic operations, people with more human capital and political capital began to be involved in business activities. Some cadres also managed to convert their political privileges into new economic advantages in this stage" (Wu, 2006: p. 391). In CGSS, 2006, there is question asking "comparatively, speaking, in the recent decade, which group of people in the following do you think obtain the most benefit?" $38.5 \%$ of the respondents think state cadres gain the most, $20.8 \%$ claim that it is private entrepreneurs, and $15 \%$ favor in foreign investors. Based on the answers, we can clearly find that most people still deem that the state cadres who hold the political capital and power benefit the most. Even in the market system, the state cadres can transfer their political power and skills to revive in the new economy. 
This is consistent with my third hypotheses of the technocratic continuity. Thus, I advocate that not only capitalists are the winners of the market transition in China, cadre still gain benefits but not as remarkable as in the pre-reform era.

\section{Impact of Marketization and Globalization on Income Inequality}

Since the reform, especially after 2001 when China joined the World Trade Organization (WTO), an increasing foreign trade and investment has flown into Chinese market. Along with this trend, the impacts of globalization and marketization from the exterior forces have greatly influenced the patterns of income equality.

First, from the Table 6 below, we can see that foreign investment is unevenly distributed which, to great extent, leads to the regional income gap. There are $87.46 \%$ of foreign enterprises investing in the eastern coastal areas, while central and western areas all together share $12.45 \%$. To the extent that the unbalanced development pace and unequal policy support in the initial stage of the reform opened the gap between regions, then the involvement of foreign investment has greatly increased the disparity.

Second, with more and more foreign-owned enterprises entering Chinese market, many SOEs face more challenges and competitions. From my regression result, we can clearly find that those who work at foreign companies earn much more than any others on average. Moreover, the income advantage in SOEs that gain all kinds of support from the state has declined greatly.

Third, "income inequality within foreign-invested enterprises is generally much higher than in state and collective enterprises" (Guan, 2001: p. 249). According to a survey conducted in Shanghai in 2005, the average annual wages of the highest level managerial personnel, such as Chief Executive Officer (CEO) and Chief Finance Officer (CFO), earn "over 400,000 yuan, which is 13.68 times higher than the ordinary workers who only earn 28,000 yuan yearly"

(http://www.ccw.com.cn/work2/culture/clcw/htm2006/2006020 8 13SBO.htm). In the foreign enterprises, the unequal salary structure is considered as a way to stimulate high efficiency under the market mechanism. Thus, SOEs also adopted this method during the structural reform in the mid-1990s and early 2000 s, which further widen the income gap within the market sector.

Table 6.

Regional distribution of the foreign-invested enterprises in China (2005).

\begin{tabular}{ccccc}
\hline \multirow{2}{*}{ Regions } & \multicolumn{2}{c}{$\begin{array}{c}\text { Number of foreign invested } \\
\text { enterprises (unit) }\end{array}$} & \multicolumn{2}{c}{$\begin{array}{c}\text { Total investment } \\
(100 \text { million USD) }\end{array}$} \\
\cline { 2 - 5 } & No. & $\%$ & No. & $\%$ \\
\hline Eastern Coastal $^{*}$ & 227401 & 87.46192 & 12729 & 86.9586 \\
Central $^{* *}$ & 21464 & 8.255385 & 1393 & 9.516327 \\
Western $^{* * *}$ & 11135 & 4.282692 & 516 & 3.525072 \\
National Total & 260000 & 100 & 14638 & 100 \\
\hline
\end{tabular}

*Includes: Beijing, Tianjin, Hebei, Liaoning, Jilin, Heilongjiang, Shanghai, Jiangsu, Zhejiang, Fujian, Shandong, Guangdong, and Hainan; ${ }^{* *}$ Includes: Shanxi, inner-Mongolia, Anhui, Jiangxi, Henan, Hubei, Hunan, Guangxi, and Chongqing; ${ }_{* * *}^{*}$ Includes: Sichuan, Guizhou, Yunan, Tibet, Qinghai, Shaanxi, Gansu, Ningxia, and Xinjiang. Source: "Chinese Statistics Yearbook (2006), Calculated from the data in the Tables 18-19 in 2006 Chinese Statistics Yearbook, Chinese Statistic Publishing House (See references)".

\section{Conclusion}

By using new data from 2006 China General Social Survey (CSSS, 2006), I conduct an OLS regression analysis on the logged annual income and gender, work experience, education, foreign language skill, party membership, type of "Hukou", geographical location, and workplace. The results of the OLS regression analysis suggest that there is estimated to be a large gender-based difference, "Hukou" discrimination and regional disparity in earnings.

The empirical results also reveal that education matters more while the political advantage of party membership drops, so do state ownership or non-market workplaces. This finding provides evidence to support Nee's theory that market transition lead to " $a$ decline of the significance of redistributive power and political capital, relative to market-based non-state economic actors, higher return to human capital than under a centrally planned economy, and new sources of economic advantage associated with entrepreneurship and hybrid/private sector employment" (Nee \& Cao, 1999: p. 807).

While my findings imply that political capital is less important, I am not ready to reject the role of party membership in determining earnings. First of all, there is a large deal of invisible income (grey income) and all kinds of welfare benefit which are not covered in the survey data, I cannot simply rely on the results from data analysis to make conclusions. Second, my research is limited in that it 1) excludes the variables of occupation and cadre status; 2) parental party membership, parental education level, and the parental social capital link; 3) "grey income" sources; and 4) welfare benefit.

For further research, I would like to take the variables of occupation and cadre status; take parental party membership, parental education level, and the parental social capital link (e.g., education) and how that turns into more market power into account to improve the model, and investigate more in the part of "grey income" and welfare benefit.

\section{Acknowledgements}

This work is based on Qiong Wu's Master's thesis. Wu's gratitude goes to her thesis committee, Dr. Barry Goetz, Dr. David Hartmann, and Dr. Yuan-Kang Wang. They have been her inspiration as she hurdles all the obstacles in the completion this research work for the support and guidance. Also, Wu thanks China General Social Survey Open Database to provide the data of 2006 for free.

\section{REFERENCES}

Bian, Y. (1994). Work and inequality in urban China. Albany, NY: State University of New York Press.

Bian, Y., \& Logan, J. R. (1996). Market transition and the persistence of power: The chaning stratification system in urban China. American Sociological Review, 61, 739-758. doi:10.2307/2096451

Bian, Y., Shu, X., \& Logan, J. R. (2001). Communist party membership and regime dynamics in China. Social Forces, 79, 805-841. doi:10.1353/sof.2001.0006

Guan, X. (2001). Globalization, inequality and social policy: China on the threshold of entry into the World Trade Organization. Social Policy and Administration, 35, 242-257. doi:10.1111/1467-9515.00231

Hauser, S., \& Xie, Y. (2005). Temporal and regional variation in earnings inequality: Urban China in transition between 1988 and 1995. Social Science Research, 34, 44-79. 
doi:10.1016/j.ssresearch.2003.12.002

Lewis, W. A. (1976). Development and distribution. In A. Cairncross, \& M. Puri (Eds.), Employment, income distribution and development strategy. London: Macmillan.

National Bureau Statistics (2006). China statistical yearbook. Beijing: China Statistical Publishing House.

Nee, V. (1989). A theory of market transition: From redistribution to markets in state socialism. American Sociological Review, 54, 663681. doi: $10.2307 / 2117747$

Rona-Tas, A. (1994). The first shall be last? Entrepreneurship and communist cadres in the transition from socialism. American Journal of Sociology, 100, 40-69. doi:10.1086/230499

Tang, W., \& Parish, W. L. (2000). Chinese urban life under reform: The changing social contract. Cambridge: Cambridge University Press.

Victor, N., \& Cao, Y. (1999). Path dependent societal transformation: Stratification in hybrid mixed economies. Theory and Society, 28, 799-834. doi:10.1023/A:1007074013540

Wang, F. (2008). Boundaries and categories: Rising inequality in post-socialist urban China. Stanford, CA: Stanford University Press.
Wu, X. (2006). Communist cadres and market opportunities: Entry into self-employment in China, 1978-1996. Social Force, 85, 389-411. doi:10.1353/sof.2006.0149

Wu, X., \& Treiman, D. J. (2004). The household registration system and social stratification in China: 1955-1996. Demography, 41, 363384. doi:10.1353/dem.2004.0010

Wu, X., \& Xie, Y. (2003). Does the market pay off? Earnings Returns to education in urban China. American Sociological Review, 68, 425442. doi: $10.2307 / 1519731$

Xie, Y., \& Hannum, E. (1996). Regional variation in earnings inequality in reform-era urban China. American Journal of Sociology, 101, 950-992. doi:10.1086/230785

Xie, Y., \& Wu, X. (2008). Danwei profitability and earnings inequality in urban China. The China Quarterly, 1, 558-581.

Xinhua (2004). Survey of Chinese officials' opinions on reform: Beijing Daily. Xinhua News Bulletin.

Zhou, X. (2000). Economic transformation and income inequality in urban China: Evidence from panel data. American Journal of Sociology, 105, 1135-1174. doi:10.1086/210401 